Ismail, A. · N. Wicaksana $\cdot$ Z. Daulati

\title{
Heritabilitas, variabilitas dan analisis kekerabatan genetik pada 15 genotip pisang (Musa paradisiaca) varietas ambon asal Jawa Barat berdasarkan karakter morfologi di Jatinangor
}

\section{Heritability, variability and genetic relationship analysis 15 accession banana (Musa paradisiaca) ambon from West Java based on morphological trait in Jatinngor}

Diterima : Januari 2015/Disetujui : Februari 2015 / Dipublikasikan : Maret 2015

CDepartment of Crop Science, Padjadjaran University

\begin{abstract}
Heritability, variability, and genetic relationship of a population are very important in the assembly of superior cultivars of bananas. The genetic parameters are the first step on the selection activities of ambon bananas. The purpose of this study is to estimate the value hertitability, variability, and genetic relationship of 15 genotype banana. The research method was used an experimental method with spatial randomized block design (RBD) with two replications. This research was conducted at the experimental field Ciparanje, Jatinangor, with a height of $753 \mathrm{~m}$ above sea level (asl). The research was conducted in May 2013 to February 2014. The results showed that the value of heritability in all 15 genotypes of ambonbanana character have a low value, which means that the environment is a major impact on the growth and development of the banana plant, while genetic has a small effect. Extensive genetic variability had seen in the wide leaves and rhizomes character. While the narrow genetic variability present in petiole length character. Wide character leaves and rhizomes (puppies) can facilitate an effective selection. In the analysis of genetic relationships of the 15 genotypes ambon bananas from West Java, only genotype AB13 who has a genetic kinship away from the other genotypes, based on Euclidian distance coefficient in the qualitative character.
\end{abstract}

\footnotetext{
Dikomunikasikan oleh Warid Ali Qosim

A. Ismail ${ }^{1} \cdot$ N. Wicaksana ${ }^{1} \cdot$ Z. Daulati2 $^{2}$

${ }^{1}$ Staf Pengajar Program Studi Pemuliaan Tanaman Faperta Unpad

Jl. Raya Bandung Sumedang, Km. 21 Jatinangor

${ }_{2}^{2}$ Mahasiswa Program Studi Pemuliaan Tanaman Faperta

Unpad

Korespondensi: adeismail_unpad@yahoo.com
}

Keywords: Analysis of genetic relationship . Heritability · West Java . Ambon banana . Variability

Sari Heritabilitas, variabilitas, dan kekerabatan dari suatu populasi sangat penting dalam perakitan kultivar unggul pisang. Parameter genetik tersebut merupakan langkah awal dalam suatu kegiatan seleksi pada populasi pisang ambon ini. Tujuan dari penelitian ini adalah mengestimasi nilai hertitabilitas, variabilitas, dan hubungan kekerabatan 15 genotip pisang ambon. Adapun metode penelitian yang digunakan merupakan metode eksperimen dengan tata ruang Rancangan Acak Kelompok (RAK) dengan ulangan dua kali. Penelitian ini dilakukan di Kebun Percobaan Ciparanje, Unpad Jatinangor, dengan ketinggian $753 \mathrm{~m}$ di atas permukaan laut (dpl). Waktu penelitian dilaksanakan pada bulan Mei 2013 sampai dengan bulan Februari 2014. Hasil penelitian menunjukkan bahwa nilai heritabilitas pada semua karakter 15 genotip pisang ambon memiliki nilai yang rendah yang artinya bahwa lingkungan berpengaruh besar terhadap pertumbuhan dan perkembangan tanaman pisang, sedangkan pengaruh genetiknya kecil. Variabilitas genetik yang luas terlihat pada karakter lebar helai daun dan rhizoma (anakan). Sedangkan variabilitas genetik yang sempit terdapat pada karakter panjang petiole. Karakter lebar helai daun dan rhizoma (anakan) dapat mempermudah efektifnya program seleksi. Kemudian pada analisis kekerabatan genetik dari ke-15 genotip pisang ambon asal Jawa Barat, hanya genotip AB13 yang memiliki kekerabatan genetik yang jauh dari genotip lain, berdasarkan jarak koefisien Euclidian dalam karakter kualitatif. 
Kata kunci: Analisis kekerabatan genetik · Heritabilitas · Jawa Barat · Pisang ambon . variabilitas

\section{Pendahuluan}

Pisang sebagai salah satu komoditi buah-buahan yang memiliki peran dan manfaatn dalam pemenuhan gizi masyarakat. Selain sebagai buah yang dikonsumsi segar, pisang juga dimanfaatkan sebagai bahan baku untuk diolah menjadi produk lainnya. Pisang (Musa paradisiaca) varietas ambon memiliki banyak manfaat dalam bidang kesehatan. Salah satunya bermanfaat untuk melancarkan pencernaan, karena memiliki kandungan serat yang tinggi. Selain itu, tidak hanya bermanfaat dalam buahnya, tetapi getah tanaman pisang ambon juga berguna sebagai penutup luka, karena memiliki kandungan kimia berupa tannin (Robinson, 1991). Tanin adalah sejenis kandungan tumbuhan yang bersifat fenol dan berfungsi untuk pertahanan diri atau sebagai antiseptik pada luka yang dapat mencegah terjadinya infeksi (Robinson, 1991).

Produksi pisang Indonesia, menempati urutan keenam setelah India, Ekuador, Brazil, Filipina dan Cina. Produksi pisang yang dihasilkan di Indonesia, 90\% untuk konsumsi dalam negeri, sedangkan untuk ekspor hanya 10\% (Direktorat Jendral Hortikultura, 2007). Di Jawa Barat, pisang termasuk komoditas unggulan nasional yang dibudidayakan secara lokal (Dinas Pertanian Jawa Barat, 2012).

Menurut Stover (1964), kendala utama pengembangan tanaman pisang komersial adalah penyakit Fusarium. Penyakit ini pernah menyerang hampir semua pisang komersial jenis Gross Michael di Amerika Latin, yang menyebabkan musnahnya 50.000 hektar tanaman pisang sampai pertengahan abad 20 . Bila hal ini dibiarkan terus-menerus, dapat diperkirakan dunia ataupun suatu daerah akan kehilangan sebagian genetik yang diperlukan untuk menghasilkan varietas unggul.

Untuk menghasilkan varietas unggul yang diinginkan, diperlukan keanekaragaman yang tinggi dan evaluasi terhadap plasma nutfah yang ada. Salah satu langkah awal untuk mengetahui lebih jauh besarnya keragaman hayati tersebut adalah dengan melakukan identifikasi keragaman genetik (Simmonds dan
Shepherd, 1955). Informasi yang telah diperoleh, selanjutnya digunakan sebagai materi perbaikan karak termelalui program pemuliaan tanaman.

Sejak tahun 2011 Laboratorium Pemuliaan Tanaman Fakultas Pertanian, Universitas Padjadjaran telah memulai penelitian mengenai keragaman jenis pisang di Indonesia, terutama di Jawa Barat (Rifiantara dkk.,2012). Menurut skema penelitian, telah dilakukan tahap pertama yaitu eksplorasi, evaluasi dan karakteristik tanaman pisang di beberapa titik daerah Jawa Barat.Hasil penelitian menunjukkan terdapat 35 jenis tanaman pisang di daerah Jawa Barat. Berdasarkan hasil analisis vegetasi, jenis pisang ambon merupakan varietas pisang yang paling mendominasi dengan nilai INP (Indeks Nilai Penting) sebesar 55,61 \% dari semua lokasi pengamatan (Prayoga dkk., 2011).

Eksplorasi tanaman pisang varietas ambon di 66 titik lokasi yang ada di Jawa Barat diantaranya Garut, Sumedang, Sukabumi, Banjar, Ciamis, Cirebon, Kuningan, dan Bandung Barat. Hasil pengamatan menunjukkan bahwa terdapat 46 genotip pisang ambon yang terbagi menjadi empat kelompok, yaitu kelompok pisang ambon lumut, ambon jepang, ambon putih, dan ambon yang belum diketahui nama jenisnya secara spesifik. Ambon yang belum diketahui nama jenisnya secara spesifik itu terdiri dari ambon hijau, ampeang, ambon ragog, dan ambon ujung, yang dianalisis melalui analisis diskriminan (Purdianty $\mathrm{dkk}$, 2012). Selanjutnya diambil dari 46 genotip menjadi 15 genotip bibit tanaman pisang (Musa paradisiaca) varietas ambon dari berbagai daerah tersebut, dan dijadikan sebagai koleksi plasma nutfah tanaman pisang, yang ditanam di Kebun Percobaan Ciparanje, Unpad, Jatinangor. Selanjutnya dalam penelitian ini, akan dilakukan identifikasi karakter morfologi vegetatif pada 15 genotip pisang (Musa paradisiaca) varietas ambon asal Jawa Barat sebagai langkah awal dari tahap seleksi.

Menurut Balitbu (1996), pisang ambon lumut, ambon putih, ambon jepang dan ampeang merupakan varietas pisang yang termasuk kelompok pisang dengan susunan genom triploid AAA. Varietas tersebut dihasilkan dari persilangan pedigre alami antara $\mathrm{Musa}$ acuminata x Musa acuminata.

Tujuan dari penelitian ini adalah mengestimasi nilai hertitabilitas, variabilitas, dan hubungan kekerabatan 15 genotip pisang ambon dan harapan kedepan bahwa hasil penelitian yang telah dilaksanakan, diharapkan dapat 
menjadi acuan program pemuliaan tanaman pisang (Musa paradisiaca) varietas ambon selanjutnya. Maka dari itu, pengamatan terhadap morfologi vegetatif tanaman pisang (Musa paradisiaca) varietas ambon dengan berbagai jenis (ambon lumut, ambon jepang, ambon putih, ampeang dan ambon) serta asal tempat bibit tanaman yang berbeda dapat membantu penelitian ini untuk mengetahui keragaman genetik dan hubungan kekerabatan diantara ke15 genotip pisang (Musa paradisiaca) varietas ambon asal Jawa Barat.

\section{Bahan dan Metode}

Penelitian ini dilakukan di Kebun Percobaan Ciparanje, Unpad Jatinangor, dengan ketinggian $753 \mathrm{~m}$ di atas permukaan laut (dpl). Waktu penelitian dilaksanakan pada bulan Mei 2013 sampai dengan bulan Februari 2014. Bahan yang digunakan dalam penelitian ini adalah 15 genotip tanaman pisang ambon (Tabel 1).

Tabel 1. Daftar Genotip yang Digunakan.

\begin{tabular}{cccc}
\hline \hline No. & $\begin{array}{c}\text { Kode } \\
\text { Genotip }\end{array}$ & Jenis Ambon & Asal \\
\hline 1 & AB 1 & Ambon & Sukabumi \\
2 & AB 2 & Ambon & Sukabumi \\
3 & AB 3 & Ambon & Sukabumi \\
4 & AB 4 & Ambon lumut & Rancakalong \\
5 & AB 5 & Ambon lumut & Lembang \\
6 & AB 6 & Ambon jepang & Ranca Kalong \\
7 & AB 7 & Ambon jepang & Ranca Kalong \\
8 & AB 8 & Ambon jepang & Cianjur \\
9 & AB 9 & Ambon putih & Cianjur \\
10 & AB 10 & Ambon putih & Tasikmalaya \\
11 & AB 11 & Ampeang & Garut \\
12 & AB 12 & Ampeang & Garut \\
13 & AB 13 & Ambon lumut & Ciamis \\
14 & AB 14 & Ambon lumut & Ciamis \\
15 & AB 15 & Ambon lumut & Ciamis \\
\hline \hline
\end{tabular}

Sumber : Lab. Pemuliaan Tanaman Unpad 2013.

Alat-alat yang digunakan antara lain meteran, form pengamatan populasi pisang ambon, deskriptor pisang berdasarkan International Union for the Protection of New Varieties of Plants (UPOV), alat tulis, alat hitung, alat ukur dan kamera digital untuk dokumentasi. Metode penelitian yang digunakan merupakan metode eksperimen dengan tata ruang Rancangan Acak
Kelompok (RAK) dengan ulangan dua kali. Metode linier dari RAK dalah sebagai berikut:

Keterangan :

$$
Y_{i j}=\mu+t_{i}+r_{j}+\varepsilon_{i j}
$$

$\mathrm{Y}_{\mathrm{ij}}$ : nilai pengamatan (respon) dari perlakuan

ke-i dan kelompok ke-j

$\mu$ : nilai tengah populasi

$t_{I}$ : pengaruh aditif dari perlakuan ke-i ( $\mathrm{i}=$ $1,2,3, \ldots t)$

$\mathrm{r}_{\mathrm{j}}$ : pengaruh aditif dari ulangan $\mathrm{ke}-\mathrm{j}(\mathrm{j}=$ $1,2,3, \ldots \mathrm{r})$

$\varepsilon_{\mathrm{ij}}$ : pengaruh galat percobaan dari perlakuan ke-i kelompok ke-j

Analisis varians dilakukan terhadap karakter yang diamati untuk menduga nilai keragaman genetik, fenotip, dan lingkungan berdasarkan Singh dan Chaudhary, (1979) (Tabel 2).

Tabel 2. Analisis Varians dan Komponen Varians Harapan.

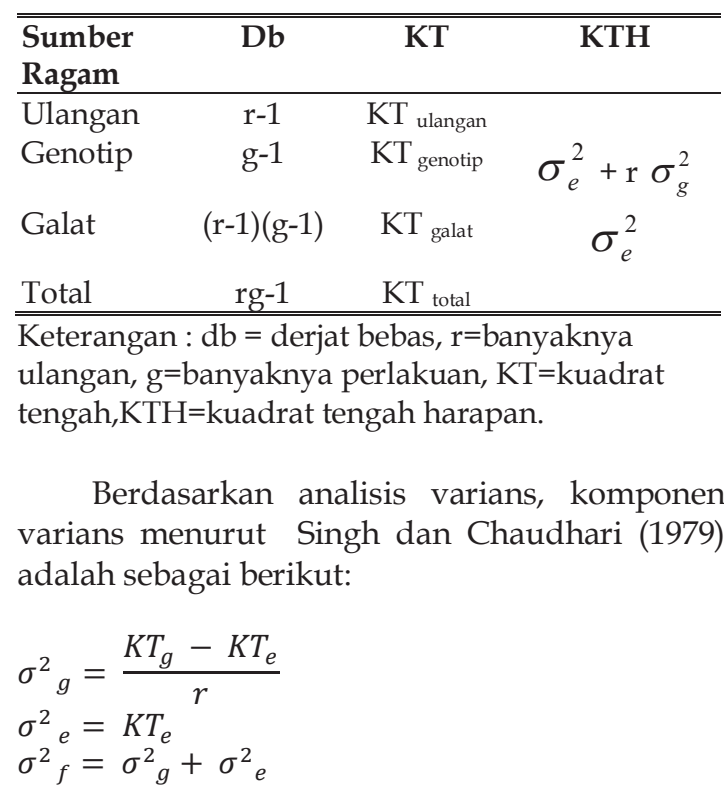

Keterangan: $\quad \sigma^{2} \mathrm{~g}=$ varians genetik

$\sigma^{2} \mathrm{e}=$ varians lingkungan $\sigma^{2} \mathrm{f}=$ varians fenotip

Analisis tingkat keragaman dapat ditentukan oleh nilai koefisien keragaman genetik (KKG) dan nilai koefisien keragaman fenotipe (KKF) dengan menggunakan metode yang dikemukakan menurut Burton dan De Vane (1953) pada setiap karakter dengan rumus sebagai berikut: 


$$
\begin{gathered}
\mathrm{KKG}=\left(\frac{\sqrt{\sigma^{2} \mathrm{~g}}}{\bar{x}}\right) \times 100 \% \\
\mathrm{KKF}=\left(\frac{\sqrt{\sigma^{2} \mathrm{f}}}{\bar{x}}\right) \times 100 \% \\
\sigma^{2} \mathrm{~g}=\text { varians genetik } \\
\bar{x}=\text { rata-rata nilai sifat } \\
\sigma^{2} \mathrm{f}=\text { varians fenotip }
\end{gathered}
$$$$
\text { Keterangan: } \quad \sigma^{2} \mathrm{~g}=\text { varians genetik }
$$

Nilai koefisien keragaman genetik dan fenotipe yang telah diperoleh dapat diklasifikasikan menjadi 4 kriteria, yaitu rendah (0-25\% dari KKG dan KKF yang terbesar), agak rendah (25-50\% dari KKG dan KKF yang terbesar), cukup tinggi (50-75\% dari KKG dan KKF yang terbesar), dan tinggi (75-100\% dari KKG dan KKF yang terbesar). Pendugaan nilai heritabilitas dalam arti luas $\left(\mathrm{H}^{2}\right)$ menurut Fehr (1987), dihitung dengan rumus:

$$
H^{2}=\frac{\sigma^{2} g}{\sigma^{2} f}
$$

Kriteria nilai heritabilitas menurut (Karmana, 1990), dapat diklasifikasikan menjadi heritabilitas rendah $\left(\mathrm{H}^{2}<0,30\right)$, heritabilitas agak rendah $\left(0,30<\mathrm{H}^{2}<0,50\right)$, heritabilitas agak tinggi $\left(0,50<\mathrm{H}^{2}<0,70\right)$ dan heritabilitas tinggi $\left(\mathrm{H}^{2}>\right.$ $0,70)$. Analisis kekerabatan genetik dilihat dengan menggunakan program NTSYSpc versi $2.10 \mathrm{q}$ yang akan menghasilkan analisis berupa dendogram dan biplot PCA (Principal Component Analysis) (Rohlf, 2001). Analisis dendogram menunjukkan keragaman dalam kelompok dan analisis PCA bertujuan untuk mengetahui karakter-karakter mana yang dapat mempe-

\begin{tabular}{|c|c|c|c|c|c|c|c|}
\hline \multirow{2}{*}{ Genotip } & \multicolumn{7}{|c|}{ Karakter Kualitatif } \\
\hline & WP & WbdPP & BDHd & KP & PAP & SMT & PT \\
\hline $\mathrm{AB} 1$ & Hijau & $\begin{array}{l}\text { Hijau kekuning- } \\
\text { kuningan }\end{array}$ & Tipe B & $\begin{array}{c}\text { Tidak } \\
\text { Lonjong }\end{array}$ & Medium & Medium & $\begin{array}{l}\text { Menyebar ke } \\
\text { samping }\end{array}$ \\
\hline AB 2 & Hijau & $\begin{array}{l}\text { Hijau kekuning- } \\
\text { kuningan }\end{array}$ & Tipe B & Medium & Medium & Medium & Ke bawah \\
\hline $\mathrm{AB} 3$ & Ungu & Merah & Tipe B & Medium & Medium & Medium & $\begin{array}{l}\text { Menyebar ke } \\
\text { samping }\end{array}$ \\
\hline $\mathrm{AB} 4$ & $\begin{array}{c}\text { Hijau kemerah- } \\
\text { merahan }\end{array}$ & Merah & Tipe B & $\begin{array}{c}\text { Tidak } \\
\text { Lonjong }\end{array}$ & Medium & Medium & $\begin{array}{c}\text { Menyebar ke } \\
\text { samping }\end{array}$ \\
\hline AB 5 & Ungu & Ungu & Tipe B & Medium & Kuat & Medium & $\begin{array}{l}\text { Menyebar ke } \\
\text { samping }\end{array}$ \\
\hline $\mathrm{AB} 6$ & Ungu & Ungu & Tipe A & Medium & Medium & Medium & $\begin{array}{c}\text { Menyebar ke } \\
\text { samping }\end{array}$ \\
\hline $\mathrm{AB} 7$ & $\begin{array}{l}\text { Hijau kekuning- } \\
\text { kuningan }\end{array}$ & Merah & Tipe B & Medium & Kuat & Medium & $\begin{array}{c}\text { Menyebar ke } \\
\text { samping }\end{array}$ \\
\hline $\mathrm{AB} 8$ & $\begin{array}{l}\text { Hijau kemerah- } \\
\text { merahan }\end{array}$ & Merah & Tipe B & Medium & Kuat & Medium & $\begin{array}{l}\text { Menyebar ke } \\
\text { samping }\end{array}$ \\
\hline $\mathrm{AB} 9$ & Setegah Hijau & Ungu & Tipe B & $\begin{array}{l}\text { Tidak } \\
\text { Lonjong }\end{array}$ & Medium & Medium & Ke bawah \\
\hline AB 10 & Hijau & Hijau & Tipe B & Medium & Medium & Medium & Ke bawah \\
\hline $\mathrm{AB} 11$ & $\begin{array}{c}\text { Hijau kekuning- } \\
\text { kuningan }\end{array}$ & Hijau & Tipe B & Medium & Medium & Medium & Ke bawah \\
\hline $\mathrm{AB} 12$ & Ungu & Merah & Tipe B & Medium & Medium & Medium & Ke bawah \\
\hline $\mathrm{AB} 13$ & $\begin{array}{l}\text { Hijau kemerah- } \\
\text { merahan }\end{array}$ & Merah & Tipe B & Medium & Medium & Medium & Ke bawah \\
\hline $\mathrm{AB} 14$ & $\begin{array}{l}\text { Hijau kemerah- } \\
\text { merahan }\end{array}$ & Merah & Tipe B & Medium & Medium & Medium & $\begin{array}{l}\text { Menyebar ke } \\
\text { samping }\end{array}$ \\
\hline AB 15 & Ungu & Ungu & Tipe A & Medium & Kuat & Medium & $\begin{array}{c}\text { Menyebar ke } \\
\text { samping }\end{array}$ \\
\hline
\end{tabular}
ngaruhi keragaman genetik terhadap hasil dari 15 genotip yang diuji.

Tabel 3.Hasil Pengamatan Karakter Kualitatif 15 Genotip Tanaman Pisang (Musa parasidiaca) Varietas Ambon.

Ismail, dkk: Heritabilitas, variabilitas dan analisis kekerabatan genetik pada 15 genotip pisang (Musa paradisiaca) varietas ambon asal Jawa Barat berdasarkan karakter morfologi di Jatinangor 

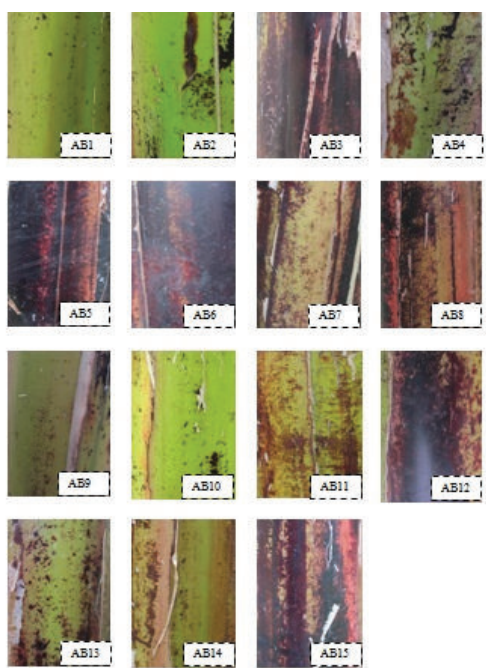

Gambar 1. Perbedaan Karakter Warna Pseudotem.
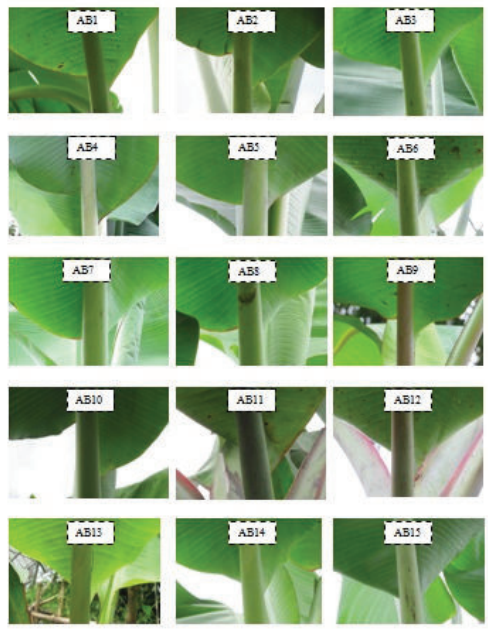

Gambar 3. Perbedaan Karakter Bentuk Dasar Helai Daun.
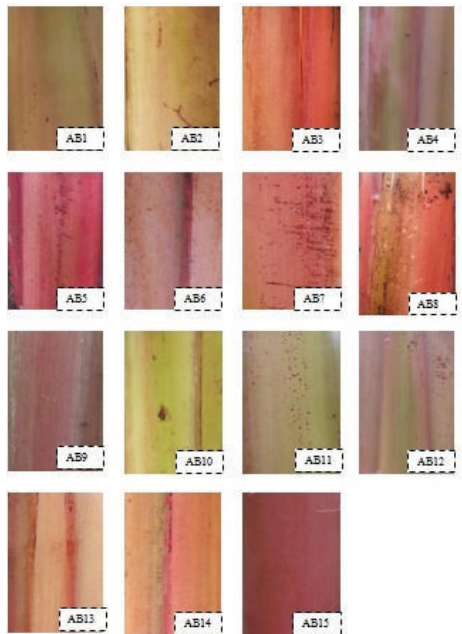

Gambar 2. Perbedaan Karakter Warna Bagian Dalam dari Dasar Pelepah Pseudotem.

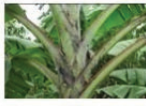

AB1

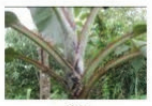

$\mathrm{AB} 4$

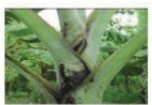

AB7

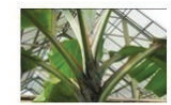

$\mathrm{AB} 2$
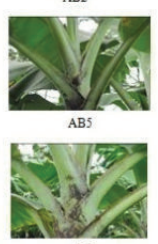

$\mathrm{ABs}$
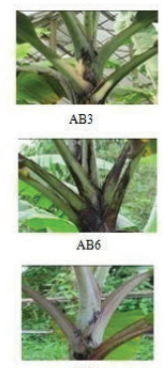

$A B 9$
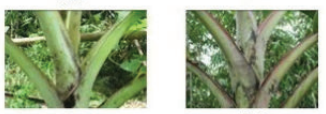

AB11
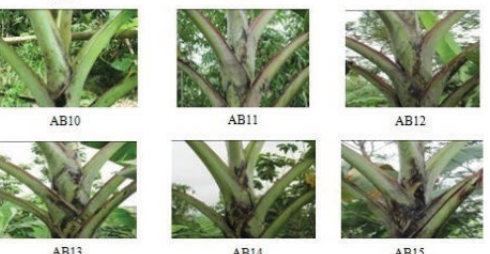

$\mathrm{AB} 12$

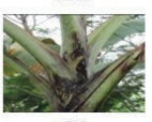

Gambar 4. Perbedaan Karakter Susunan Mahkota Tanaman.

Tabel 4. Nilai Variabilitas Genetik dan Variabilitas Fenotip pada Karakter-karakter yang Diamati.

\begin{tabular}{lrrrrrr}
\hline \hline \multirow{2}{*}{ Karakter } & \multicolumn{3}{c}{ Variabilitas Genetik } & \multicolumn{3}{c}{ Variabilitas Fenotipe } \\
\cline { 2 - 7 } & \multicolumn{1}{c}{$\mathbf{\sigma}_{\mathbf{g}}$} & KKG (\%) & Kriteria & \multicolumn{1}{c}{$\mathbf{\sigma}_{f}^{2}$} & KKF (\%) & Kriteria \\
\hline Panjang pseudostem & 256,07 & 11,55 & Cukup Tinggi & 2591,91 & 36,75 & Cukup Tinggi \\
Diameter pseudostem & 2,51 & 14,92 & Cukup Tinggi & 15,72 & 37,39 & Cukup Tinggi \\
Panjang petiole & 0 & 0 & Rendah & 12,21 & 15,92 & Agak Rendah \\
Panjang helai daun & 320,36 & 13,42 & Cukup Tinggi & 2685,49 & 38,86 & Cukup Tinggi \\
Lebar helai daun & 83,89 & 18,06 & Tinggi & 479,99 & 43,19 & Tinggi \\
Rhizoma (anakan) & 0,47 & 19,54 & Tinggi & 3,63 & 54,28 & Tinggi \\
\hline \hline
\end{tabular}




\section{Hasil dan Pembahasan}

Berdasarkan hasil pengamatan karakter kualitatif (Tabel 3) yang terdiri dari warna pseudostem, warna bagian dalam pelepah pseudostem, bentuk dasar helai daun, kelon-jongan pseudostem, pewarnaan anthocyanin, susunan dari mahkota tanaman, dan pertum-buhan tanaman terdapat keragaman pada seluruh karakter. Keragaman ini dapat ditunjukan oleh Gambar 1 warna pseudotem, Gambar 2 warna bagian dalam dari dasar pelepah pseudotem, Gambar 3 bentuk dasar helai daun dan Gambar 4 susunan mahkota tanaman.

Hasil perhitungan nilai variabilitas genetik dan fenotip dapat dilihat pada Tabel 4. Dari Tabel 4 terlihat variabilitas genetik yang sempit terdapat pada karakter panjang petiole. Sedangkan variabilitas genetik yang luas terdapat pada karakter lebar helai daun dan rhizoma (anakan).

Hasil penelitian menunjukkan bahwa nilai heritabilitas terhadap semua karakter yang diamati menghasilkan nilai yang termasuk kriteria rendah (Tabel 5). Meskipun terdapat nilai negatif maka dianggap nol. Nilai haritabilitas yang rendah ini mengartikan bahwa lingkungan berpengaruh besar terhadap pertumbuhan dan perkembangan tanaman pisang ambon asal Jawa Barat ini, sedangkan pengaruh genetiknya kecil.

Tabel 5. Nilai Heritabilitas pada Karakterkarakter yang Diamati.

\begin{tabular}{lrl}
\hline \hline \multicolumn{1}{c}{ Karakter } & \multicolumn{1}{c}{$\mathbf{H}^{\mathbf{2}}$} & Kriteria \\
\hline Panjang pseudostem & 0,19 & Rendah \\
Diameter pseudostem & 0,16 & Rendah \\
Panjang petiole & 0 & Rendah \\
Panjang helai daun & 0,11 & Rendah \\
Lebar helai daun & 0,18 & Rendah \\
Rhizoma (anakan) & 0,13 & Rendah \\
\hline \hline
\end{tabular}

Selanjutnya berdasarkan analisis keragaman genetik menggunakan software NTSYS versi 21.0q menunjukkan keragaman genetik luas dengan jarak Euclidian 0,00-18 pada karakter kualitatif dan 0,00-7 pada karakter kuantitaif (Gambar 5 dan 6). Pada Gambar 5dan 6 terlihat dendogram terbagi ke dalam tiga klaster yakni klaster IA, IB dan klaster II.

Pola penyebaran diantara 15 genotip pisang ambon asal Jawa Barat berdasarkan karakter kualitatif ditunjukkan pada Gambar 7.
Grafik terbagi menjadi 4 kuadran.Kuadran I terdiri dari genotip AB10 dan AB13 dengan kontribusi karakter bentuk helai daun, warna pseudostem dan pertumbuhan tanamanyang mempengaruhi adanya variasi. Kuadran II terdapat genotip $\mathrm{AB} 1, \mathrm{AB} 4, \mathrm{AB} 7$ dan $\mathrm{AB} 9$ dengan kontribusi karakter pewarnaan anthocyanin pseudostem yang mempengaruhi adanya variasi. Di kuadran III terdiri dari genotip AB3, AB6, AB8, dan AB15 dengan kontribusi karakter warna helai daun dan susunan mahkota tanaman yang mempengaruhi adanya variasi.Di kuadran IV terdapat genotip AB2, AB5, AB11, AB12 dan AB14 dengan kontribusi karakter warna bagian dalam pelepah pseudostem dan kelonjongan pseudostem yang mempengaruhi adanya variasi.

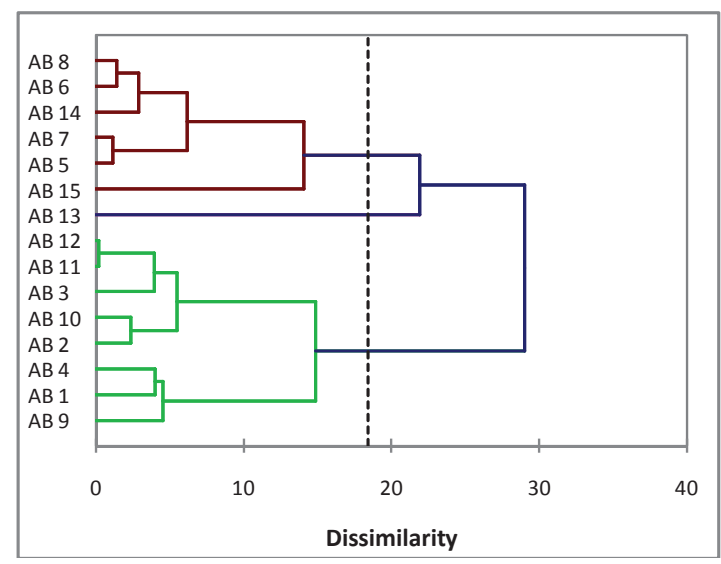

Gambar 5. Dendogram Keragaman Genetik 15 Genotip Tanaman Pisang Ambon Asal Jawa Barat Berdasarkan Karakter Kualitatif.

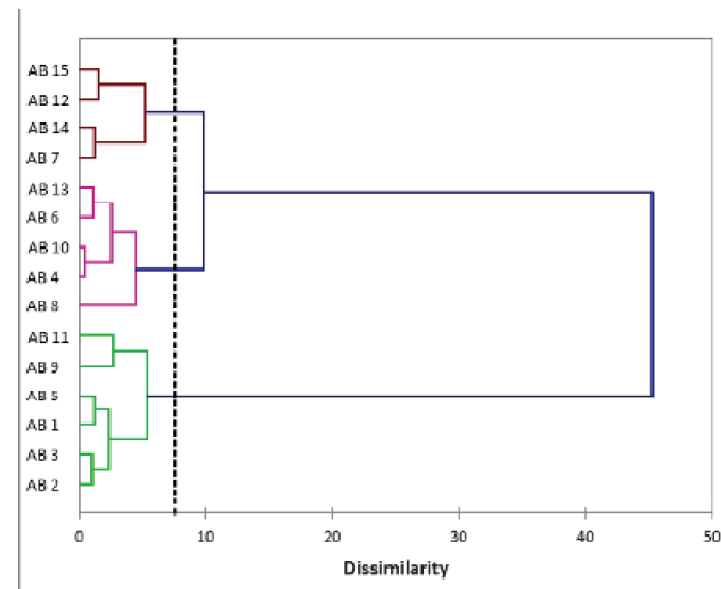

Gambar 6. Dendogram Keragaman Genetik 15 Genotip Tanaman Pisang Ambon Asal Jawa Barat Berdasarkan Karakter Kuantitaif. 
Pola penyebaran diantara 15 genotip pisang ambon asal Jawa Barat berdasarkan karakter kuantitatif ditunjukkan pada Gambar 8. Grafik terbagi menjadi 3 kuadran.Kuadran I terdiri dari genotip AB3, AB4, AB10 dan AB15 dengan kontribusi karakter panjang petiole dan lebar helai daun yang mempengaruhi adanya variasi.Kuadran II terdapat genotip AB5, AB6, AB9 dan AB13 dengan kontribusi karakter diameter pseudostem yang mempengaruhi adanya variasi. Di kuadran III terdiri dari genotip AB7, AB8, AB11 dan AB14 dengan kontribusi karakter panjang pseudostem, panjang helai daun dan rhizoma (anakan) yang mempengaruhi adanya variasi.

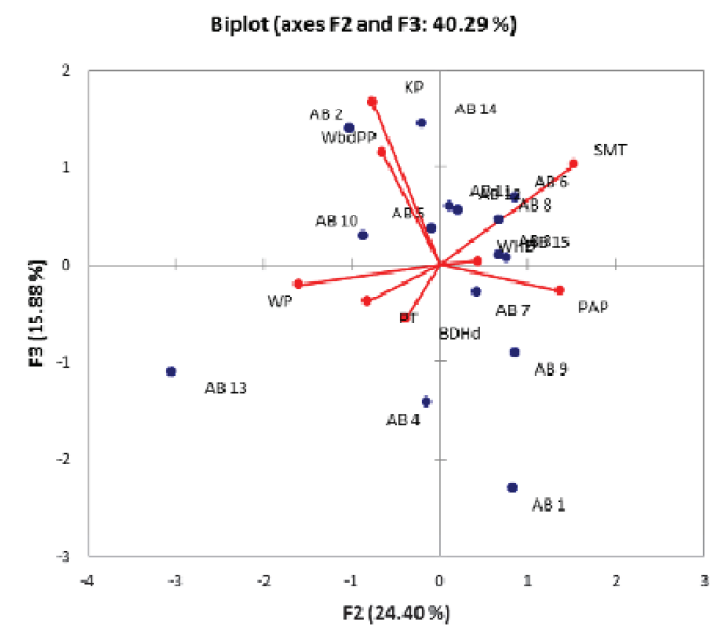

Gambar 7. Pola Penyebaran 15 Genotip Pisang Ambon Lokal Jawa Barat Berdasarkan 14 Karakter Kualitatif.

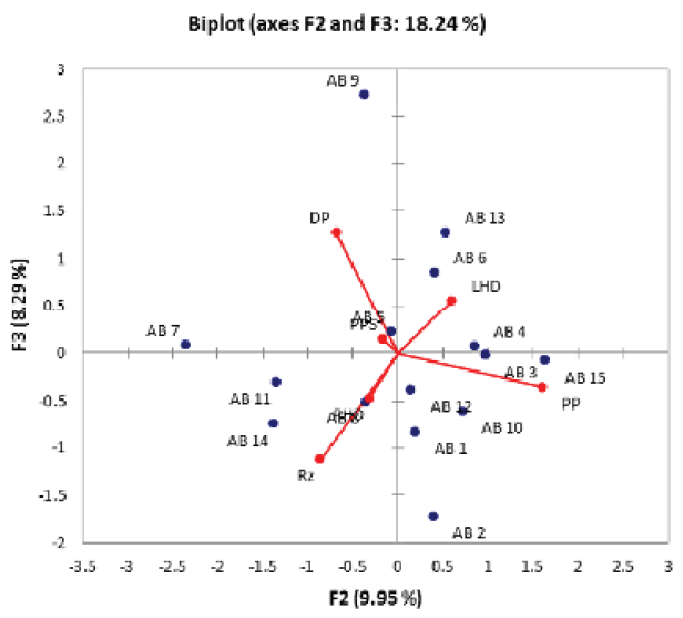

Gambar 8. Pola Penyebaran 15 Genotip Pisang Ambon Lokal Jawa Barat Berdasarkan 14 Karakter Kuantitaif.

\section{Kesimpulan dan Saran}

Semua karakter yang diamati memiliki nilai heritablitas rendah. Variabilitas genetik yang luas terlihat pada karakter lebar helai daun dan rhizoma (anakan). Berdasarkan jarak koefisien euclidian yang dihasilkan oleh analisis kekerabatan genetik dalam karakter morfologi, genotipAB13 memiliki hubungan kekerabatan yang jauh dengan genotip lain.

\section{Ucapan Terima Kasih}

Penelitian ini di biayai oleh Lembaga Penelitian dan Pengabdian kepada Masyarakat (LPPM) Universitas Padjadjaran yang telah mendanai penelitian ini melalui skema PKILAB (Penelitian Peningkatan Kompetensi Keilmuan Laboratorium Universitas Padjadjaran) 2013.

\section{Daftar Pustaka}

Burton, G.W. dan E.H. De Vane. 1953. Estimating heritability in tall fescue (Festuca arundinacea) from replicated clonal material. Agronomy Journal 45: 478-481.

Dinas Pertanian Jawa Barat, 2013. Sentra Produksi Komoditas Unggulan Jawa Barat dan Unggulan Nasional.

Fehr, W.R. 1987. Principles of Cultivar Development Theory and Technique. Macmillan Publishing Company. New York.

Hermiati, Nani. 2004. Diktat Dasar Pemuliaan Tanaman. Fakultas Pertanian. Universitas Padjadjaran.Tidak dipublikasikan.

Karmana, M.H., A. Baihaki, G. Satari, T. Danakusuma dan A. H. Permadi. 1990. Variasi genetik sifat-sifat bawang putih di Indonesia. Zuriat, Vol. 01 No. 1 Edisi Januari-Juni 1990.

Prayoga M. K., Ismail A., Haeruman K., Murdaningsih. 2011. Keanekaragaman Jenis Pisang di Jawa Barat. Prosiding pada Seminar Peripi 'Pemanfaatan Sumber Daya Genetik Lokal Mendukung Industri Perbenihan Nasional' Universitas Padjadja-ran 10 Desember 2011. Bandung.

Rifiantara A., Ismail A., Murdaningsih., Karuniawan A., Nursuhud., Purnama A. 
2012. Keanekaragaman hayati pisang ambon (Musa paradisiaca) pada tingkat ekosistem di Jawa Barat. Jurnal Seminar PERIPI.

Robinson, Trevor. 1991. Kandungan Organik Tumbuhan Tinggi. ITB: Bandung, Hal: 71.

Rohlf. F. J. 2001. NTSYpc. Numerical Taxonomy and Multivariate analysis System.Exeter Software, New York USA.

Simmonds NW, Shepherd K. 1955. Taxonomy and Origins of Cultivated Bananas. J Linn Soc Bot 55:302-312.

Singh, R.K., dan B.D. Chaudhary. 1979. Biometrical Methods in Quantitative Genetic Analysis. Kaliyani Publisher. New Delhi.

Stover, R.H., and Simmonds, N.W. 1964. Bananas.Tropica Agriculture Series Third Edition. Longman Scientific \& Technical New York. 461p. 